\title{
Productive Entrepreneurship in the EU and Its Barriers in Transition Economies: A Cluster Analysis
}

\author{
Zsuzsanna K. Szabo, Emilia Herman \\ "Petru Maior" University of Tg. Mures \\ 1 N. Iorga, 540088 Tg. Mures, Romania \\ zsuzsanna.szabo@ea.upm.ro, emilia.herman@ea.upm.ro
}

\begin{abstract}
A wide-spectrum of registered entrepreneurial activities can be observed in transition economies. However, the outcomes are not reflected in the projected economic growth. This article examines the entrepreneurial performance of transition economies in the European context and presents a research approach on the relationship between economic development, institutions and entrepreneurship in order to identify needs to eliminate barriers to productive entrepreneurship. The authors present a cluster analysis of EU Member States. In this respect, the scientific approach is a necessity. The findings of the study can be useful for policymakers to formulate policies in concordance with priorities.
\end{abstract}

Keywords: productive entrepreneurship; transition; value creation; cluster analysis

\section{Introduction}

Entrepreneurship is considered the "main driver of economic growth" [12]. It is also widely acknowledged that entrepreneurship has a positive impact on different indicators measuring the level of economic development. Moreover, entrepreneurship is a topic that concerns potential entrepreneurs who are interested in starting their own businesses as well decision makers who are willing to formulate adequate policies aiming to enhance a more favorable environment for businesses. Entrepreneurship has developed greatly over the last 20 years and it continues to grow. Entrepreneurship was studied in its multidimensionality and a tremendous number of research papers have been published. Entrepreneurship scholars identified a large variety of entrepreneurial activities across different societies all over the world, such as formal/informal, legal/illegal and necessity/opportunity entrepreneurship, respectively. 
This paper focuses on the entrepreneurial activities output by investigating the entrepreneurship impact on economic development. In this respect, we concentrate on the efficiency and quality of the entrepreneurial activities. The main purpose of the study is to analyze the connection between entrepreneurial activities and value creation.

In his 1990 fundamental paper, Baumol, distinguished between productive, unproductive, and even destructive entrepreneurship [5]. He claimed that while the level of entrepreneurship was constant over time and across the phases of development, the quality of entrepreneurship varied considerably. According to Baumol, entrepreneurial differences were determined by institutions, not by the degree of the underlying entrepreneurial spirit. Baumol's theory was recognized as a significant contribution to the economics of entrepreneurship literature [26]. A theoretical and empirical exploration of the productive, unproductive and destructive entrepreneurship was published in 2008 by Sauka [22]. The conceptual framework developed by Sauka, also presents a fundamental contribution to the entrepreneurship literature. It opens a research direction with the aim to reduce the differences between the outputs of entrepreneurial activities between countries. Sauka measured productive entrepreneurship in terms of growth on societal and venture level. The environment, in which the entrepreneurial process is taking place, determines the quality of the individuals' skills, abilities and transformation in outputs [23], [24]. To assure productive entrepreneurship, the role of entrepreneurial orientation (EO) was recognized as significant. Sauka [22] and Miller [20] proposed the following dimensions of EO: Innovativeness, proactiveness and risk-taking. Later, in 1996, another two dimensions were introduced: competitive aggressiveness and autonomy [19]. Innovation is considered the engine of growth, being an important element of development achievements [14]. Its impact on the growth of the innovative SME's is significant, as confirmed by official data [12]. Therefore, innovative entrepreneurship started to be considered a key factor of modern economic development [12]. Productive entrepreneurship generates economic wealth through innovation and by filling gaps in the market. Douhan and Henrekson [8] confirm a strong positive relationship between productive entrepreneurship and an economy's innovativeness as well as its ability to adapt. Entrepreneurial behavior (EB) is treated in various ways in literature. Research papers prove the role of institutions in the output of entrepreneurial activity and underline the difference between quality and quantity entrepreneurship. Estrin et al. [10]; Aidis and Sauka [1] determined specific types of EB in transition countries.

This article examines the performance of entrepreneurial activities in transition economies, in the European context, to identify the barriers which must be eliminated through adequate policies in order to catch up with developed economies. We will analyze the entrepreneurial activity through the generated output, in order to determine needs, to eliminate the barriers for productive entrepreneurship. 


\section{Research Questions, Hypotheses and Objectives}

A reduced number of research studies, which focus on productive, unproductive and destructive entrepreneurship, have been published. Entrepreneurship exists all over the world, but the importance of entrepreneurship does not consist only in the quantitative presence of entrepreneurship, but in the entrepreneurial activities impact on economic development. The conceptual framework of productive entrepreneurship was developed by Sauka, who underlined the importance of analyzing the firms' activities output on both, venture and societal levels [22]. Researchers started to focus on the efficiency of entrepreneurship and studies were published which treated the quantity and quality of entrepreneurship separately. In order to measure entrepreneurship, the Global Entrepreneurship Index was introduced by Acs and Szerb in 2009 [2], and was continuously developed and renamed as the Global Entrepreneurship and Development Index (GEDI) by the same scientists [3]. It is widely recognized that technology and innovation have a positive impact on the entrepreneurial performance and have a significant role in the social and economic development through the created output. At the same time, significant differences can be observed in innovation capacity and performance between EU Member states [27]. Estrin et al. [10] present the most important role of institutions in "the rising SME contribution to employment and value added (output)." Based on the literature, three main institutions are considered relevant for entrepreneurship: property rights [17]; state-sector [5] and financial sector [16], [6], and all of them are considered barriers to entrepreneurship. We believe that, in order to reduce the gap between developed and transition economies, and transform the entrepreneurial activity in a productive way, it is necessary to make a detailed analysis of entrepreneurial activities and study the financial, institutional, human capital, socio-cultural factors and their impacts on the entrepreneurial activities output both within and across societies. The study is focused on the following research topics.

Question 1: To evaluate the performance of the entrepreneurial activity in transition economies, we will first determine a comparative view of entrepreneurship in the EU. We are interested in studying the relationship between transition economies and developed economies as it relates to entrepreneurship and the implications for socio-economic development and seeing whether there is a meaningful difference or not. We will measure the intensity via TEA-Total early-stage Entrepreneurial Activity [15], and the entrepreneurial performance via GEDI methodology.

H1: The total early-stage Entrepreneurial Activity (TEA) has an increasing tendency in transition economies.

H2: The efficiency of entrepreneurship is determined by the level of stages of economic development.

H3: GEDI and GEM-TEA Index measure different aspects of entrepreneurship. 
Question 2: We will explore the entrepreneurship in its multidimensionality using 12 variables which highlight economic development, entrepreneurship, institutional development, innovation and technological readiness. To gauge the economic performance various indicators such as GDP/capita, the labor productivity and the Global Competitiveness Index (GCI) were used. Innovation capacities and performance will be measured by the Summary Innovation Index (SII) and a nation's or community's degree of preparation to participate in and benefit from information and communication technology developments via NRI index. The institutional environment will be expressed by the Ease of Doing Business Rank (DB) and the Index of Economic Freedom. Entrepreneurship will be defined by GEDI, Necessity-Driven Entrepreneurial Activity indicator (TEA necessity) and Improvement-Driven Opportunity Entrepreneurial Activity (TEA opportunity), as a percentage of Total early-stage Entrepreneurial Activity. Innovative entrepreneurship will be analyzed by SMEs introducing product or process innovations and SMEs introducing marketing or organizational innovations as a percentage of SMEs. We will realize a cluster analysis of EU member states.

H4: The EU Member States can be enrolled in different clusters based on the entrepreneurial performance.

Question 3: We are interested to see the connection between the intensity of entrepreneurial activity and the generated output from it. It is widely acknowledged that the generated output has an impact on the economic development. In the pursuit of studying whether the entrepreneurial activity in transition economies is productive or not, we will analyze the efficiency of entrepreneurship and we will compare the output on both the venture and societal level between EU member states.

H5a: The output on both the venture and societal level shows high differences between transition and developed economies.

$H 5 b$ : In transition economies, entrepreneurship is productive on the societal level, having a significant role in the generation of employment.

Question 4: In order to improve the outputs of the different types of entrepreneurial activities, we will study the different aspects of entrepreneurial activities using both individual and institutional data. Some researchers show that the institutional environment has a considerable impact on the output of entrepreneurial activities. Sauka [22] studied how environment and institutions can moderate the entrepreneurial orientation and entrepreneurial behavior having impact on outputs. We will compare the results of transition economies relative to their peer countries in the same cluster. A comparative study between clusters will be realized as well. The aim of this investigation is to identify the barriers for transition economies and provide policy suggestions on how to encourage productive entrepreneurship. Entrepreneurial attitudes have a fundamental impact 
on factor driven economies, the entrepreneurial activity on the efficiency driven economies and the entrepreneurial aspiration on innovation driven economies.

H6: The position of the transition economies regarding the connection between innovation and economic development measured by GDP/capita is far from the position of the developed economies. Within the cluster, the situation is comparatively similar. The low level of innovative capacity presents a barrier to productive entrepreneurship.

H7: The high quality of institutions can be expected to have a significant role on the quality of entrepreneurial activity, and thus on the level of the economic development. The institutional environment presents an obstacle to productive entrepreneurship in transition economies.

H8: On the venture level, large enterprises are more productive. The increasing number of large enterprises in transition economies should be pursued aggressively because of its strong relationship within economic development.

\section{Methodology and Data}

We used publicly available databases such as GCI, Global Competitiveness Index (2007-2013), introduced by Xavier Sala-i-Martin in 2004, countries rank published annually by World Economic Forum, using different indicators grouped by 12 pillars [29]; SII, Summary Innovation Index (2012-2013) - the Innovation Union Scoreboard divided the EU Member States into four groups based on their summary innovation performance [12]; NRI, Network Readiness Index (2012-2013), defined as a nation's or community's degree of preparation to participate in and benefit from information and communication technology developments [30]; Ease of Doing Business Rank [28]; Index of Economic Freedom, according to The Heritage Foundation [21], covering all aspects of economic environment, consisting of four pillars of economic freedom care and involving both individuals and governments (Rule of Law, Limited government, Regulatory efficiency, Open markets); GEM, Global Entrepreneurship Monitor, an ongoing multinational project created to investigate entrepreneurship [15], [32]; EUROSTAT database [13]; GEDI, Global Entrepreneurship and Development Index, which captures the multidimensional nature of entrepreneurship, the qualitative and quantitative aspects of entrepreneurial activity, using both individual and institutional data, [4]. The different types of used indicators characterizes the entrepreneurial activity, the business environment from different points of view and, in this way, they sustain the methodology giving a strong fundamental base for this study.

In the pursuit of obtaining a comparative view of the performance of entrepreneurship, we used the Principal Component Analysis (PCA). PCA is a 
useful multivariate statistical technique that is used to identify patterns in data, and express the data in a way that highlights similarities and differences [25]. PCA is an advantageous method because it reduces the dimensionality of a data set consisting of a large number of interrelated variables to a few factors or principal components, while retaining as much as possible of the variation present in the data set [18]. In this study, the principal component analysis with Varimax rotation and Kaiser Normalization is used to transform the set of originally mutually correlated variables into a new set of independent variables. Based on the entrepreneurship performance of the transition economies in the European context, we will establish a classification of the European countries using cluster analysis. Cluster analysis finds peer countries and identifies relatively homogenous groups of countries based on the selected variables/principal components. The principal components obtained by PCA became the basis for cluster analysis, which led to the identification of the homogeneous groups of countries. Therefore, at first we used the hierarchical cluster analysis, using Ward's method and the Euclidian distance in order to determine the number of clusters. This method was followed by the k-means cluster analysis [11]. $\mathrm{K}$-means cluster analysis is a commonly used procedure to identify relatively homogeneous groups of cases based on selected characteristics. It was proven that principal components (PCA) are actually the continuous solution of the cluster membership indicators in the K-means clustering method. Thus, the PCA automatically performs data clustering according to the K-means objective function, the solution to Kernel K-means is given by Kernel PCA components [7]. Descriptive statistics was used to thoroughly study the internal and external interpretation of the results obtained using the principal components analysis, as well as the cluster analysis. To verify the relationships suggested by the hypotheses, regression analysis was employed. The quality of prediction is measured by the value $\mathrm{R}^{2}$. To measure the strength of association between two ranked variables, the Spearman's rank-order correlation was used. For data processing, the SPSS software package was used.

\section{Results and Analysis}

Regarding hypothesis $\boldsymbol{H 1}$, longitudinal data was used and we can observe, as can be seen in Figure 1, that in transition economies the total early-stage Entrepreneurial Activity (TEA) has an increasing tendency. Differences can be observed among countries, for some of them the increasing tendency is more accentuated than for the others. On the other hand, these countries did not record performance on venture-level, in terms of GDP/capita and labor productivity, [13]. Some transition economies such as Poland, Slovakia and Bulgaria are missing because of data availability for the period of 2007-2010. 
Next, we used cross-sectional data to measure the entrepreneurial activity outputs and their impact on economic development. A study on the performance of entrepreneurship is required because, from the competitiveness point of view, transition countries lag behind developed economies.

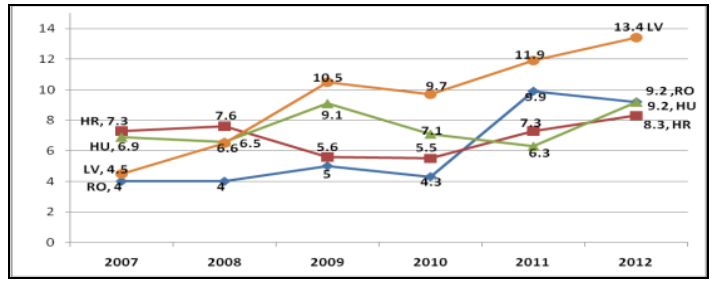

Figure 1

Source: [32]

Total early-stage Entrepreneurial Activity (TEA)

To analyze the impact of the stages of the economic development on entrepreneurial activity efficiency, hypothesis $\boldsymbol{H} \boldsymbol{2}$ was tested. To see the relationship between Necessity-Driven Entrepreneurial Activity indicator (calculated as percentage of those involved in Total early-stage Entrepreneurial Activity-TEA) and the stage of economic development, measured by GDP/capita, we calculated the Spearman correlation coefficient $\rho$. The calculated $\rho=-0.619$ indicates a moderate negative relationship, as can be seen in Figure 2a.

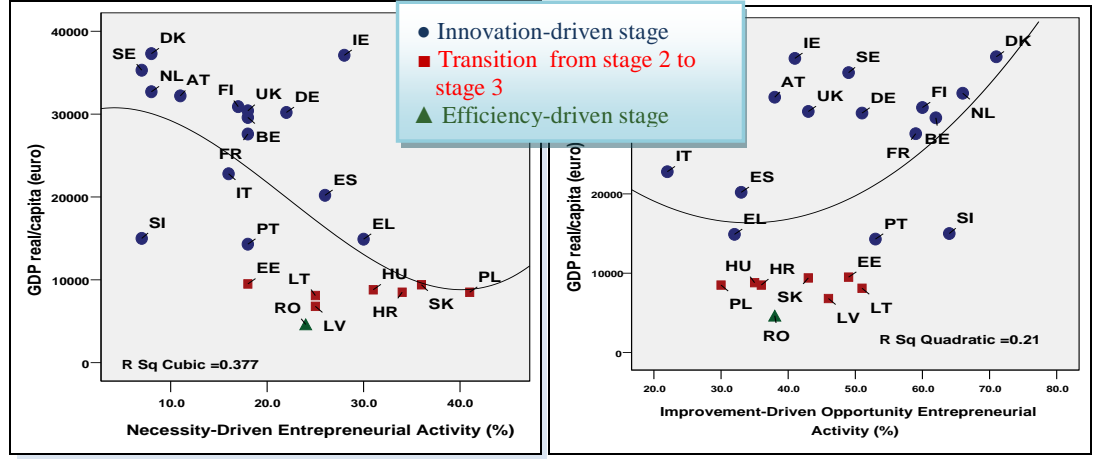

Source: Own calculations based on data provided by [13], [29], [32]

Figure 2

(a) Negative moderate correlation between "necessity entrepreneurship" and economic development

(b) Positive moderate to low correlation between "opportunity entrepreneurship" and economic development

In the case of Improvement-Driven Opportunity Entrepreneurial Activity, the calculated Spearman correlation coefficient is $\rho=+0.398$, which indicates that the correlation is a moderate to low positive (Figure 2b). Thus, it is confirmed that necessity driven entrepreneurship decreases with the evolution of the stages of the economic development and the opportunity driven entrepreneurship has a high 
impact on the growth of the GDP. The efficiency of entrepreneurship, measured as output on venture level, increases with the evolution of the stages of economic development.

Examining results of testing $\mathrm{H} 3$, a significant relationship is revealed between GEDI and economic development (Spearman correlation coefficient $\rho=+0.797$, $\mathrm{R} 2=0.803, \mathrm{p}<0.001)$. A negative moderate to low relationship between GEMTEA index and economic development was indicated by the calculated Spearman correlation coefficient: $\left.\rho=-0.409, \mathrm{R}^{2}=0.235, \mathrm{p}<0.1\right)$. Our results highlight that GEDI and GEM-TEA index measure different aspects of entrepreneurship as can be seen in Figures $3 \mathrm{a}$ and $3 \mathrm{~b}$. It can be noticed that GEDI is focused on the quality and TEA on the quantity of entrepreneurial activity.

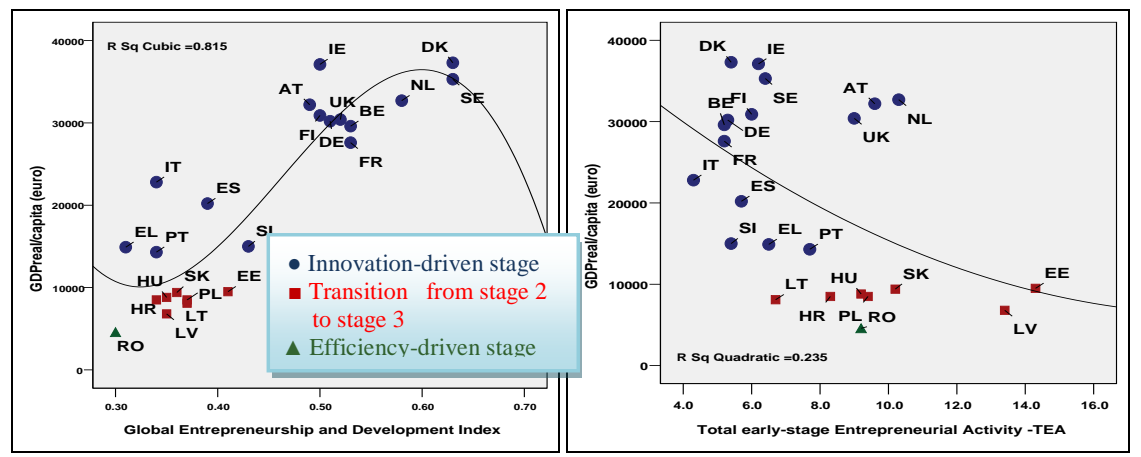

Source: Own calculations based on data provided by [4], [13], [29], [32]

Figure 3

(a) Positive relationship between GEDI and economic development in EU23 countries

(b) Negative moderate to low relationship between TEA and economic development, in EU23 countries

In order to test hypothesis $\boldsymbol{H 4}$, we selected indicators from publicly available databases. We used a descriptive analysis of the considered indicators to highlight the heterogeneity of the entrepreneurial activity of European countries. A study on the quality of entrepreneurship needs a complex analysis. We used 12 variables (Table 1) and we analyzed 23 EU member states (Luxemburg, Malta, Czech Republic, Bulgaria, Cyprus data missing) focusing on the following: economic development, entrepreneurship, institutional development, innovation and technological preparedness.

The number of valid cases for this set of variables $(\mathrm{N})$ is 23 . PCA requires a strong relationship between the variables included in the analysis. The correlation matrix obtained based on our own calculation fulfilled the requirements. Starting from the significant positive or negative correlations, identified between the initial variables, using PCA (Rotation method: Varimax with Kaiser Normalization; rotation converged in 3 iterations), the information of 12 of the variables can be represented by two components. The two components explain $80.03 \%$ of the total variance in the variables which are included in the components. 
Table 1

Variables included in the analysis PCA and cluster. Descriptive Statistics

\begin{tabular}{lrrrrr}
\hline Variables & N & Minimum & Maximum & Mean & Std.Deviation \\
\hline Global Entrepreneurship and & 26 & .30 & .63 & 0.428 & 0.101 \\
$\begin{array}{l}\text { Development Index- GEDI } \\
\text { GDP/capita }\end{array}$ & 26 & 3700 & 37300 & 19500.0 & 11348.83 \\
TEA opportunity- TEA opp. & 23 & 22.00 & 71.00 & 46.609 & 12.911 \\
$\begin{array}{l}\text { TEA necessity-TEA-nec } \\
\text { Network Readiness Index - }\end{array}$ & 23 & 7.00 & 41.00 & 21.130 & 9.550 \\
$\begin{array}{l}\text { NRI } \\
\text { Global Competitiveness }\end{array}$ & 26 & 3.86 & 5.98 & 4.777 & 0.665 \\
$\begin{array}{l}\text { Index - GCI } \\
\text { Summary Innovation Index- }\end{array}$ & 26 & .93 & 5.54 & 4.688 & 0.511 \\
$\begin{array}{l}\text { SII } \\
\text { SMEs introducing product }\end{array}$ & 26 & 13.17 & 57.00 & 33.844 & 12.639 \\
$\begin{array}{l}\text { or process innovations - } \\
\text { SMEs-PP }\end{array}$ & & & & \\
$\begin{array}{l}\text { SMEs introducing marketing } \\
\text { or organizational }\end{array}$ & 26 & 16.31 & 60.55 & 36.049 & 10.465 \\
innovations - SMEs-Mk & & & & & \\
$\begin{array}{l}\text { Index of Economic Freedom } \\
- \text { IEF }\end{array}$ & 26 & 55.40 & 76.10 & 68.496 & 5.173 \\
$\begin{array}{l}\text { Ease of Doing Business } \\
\text { Rank- DB }\end{array}$ & 26 & 1.00 & 26.00 & 13.500 & 7.649 \\
Labor productivity-LP & 26 & 44.30 & 142.60 & 91.642 & 24.478 \\
\hline
\end{tabular}

Source: Own calculations based on data [4], [12], [13], [21], [28], [29], [30], [32]

The first principal component (PC1), which explains $67.41 \%$ of total variance, includes seven variables (Table 2). Six of these variables can be specific to an efficient and productive entrepreneurship, having a positive impact on national competitiveness: institutional variables (DB, IEF), NRI, GEDI, GCI and TEA opportunity-improvement driven opportunity entrepreneurial activity. This component (PC1) is negatively correlated with the TEA necessity-driven entrepreneurial activity. Thus, the necessity driven entrepreneurship cannot create economic development measured by GDP/capita. The second principal component $(P C 2)$ explains $12.62 \%$ of total variance and includes five variables (Table 2): the innovativeness of entrepreneurs (measured by the number of SMEs with marketing and process innovation), the innovation performance (SII), labor productivity and economic development (measured by GDP/capita). All variables have a positive contribution to the creation of the component. 
Table 2

Principal Components for EU countries

(Rotated Component Matrix)
The results of the cluster analysis: Final cluster centers and ANOVA

Table 3

\begin{tabular}{|c|c|c|c|c|c|c|c|c|c|}
\hline \multirow{2}{*}{$\begin{array}{c}\text { Initial } \\
\text { variables }\end{array}$} & \multirow{2}{*}{ PC 1} & \multirow{2}{*}{ PC2 } & \multicolumn{7}{|c|}{ Final Cluster Centers } \\
\hline & & & & \multirow{2}{*}{$\begin{array}{c}\text { Cluster } \\
1\end{array}$} & \multirow{2}{*}{\multicolumn{2}{|c|}{\begin{tabular}{|c|} 
Cluster \\
2
\end{tabular}}} & \multirow{2}{*}{$\begin{array}{c}\text { Cluster } \\
3\end{array}$} & \multirow{2}{*}{\multicolumn{2}{|c|}{$\begin{array}{c}\text { Cluster } \\
4\end{array}$}} \\
\hline \multirow{6}{*}{$\begin{array}{l}\text { DB } \\
\text { IEF } \\
\text { NRI } \\
\text { GEDI } \\
\text { GCI } \\
\text { TEAop } \\
\text { TEAnec }\end{array}$} & \multirow{2}{*}{$\begin{array}{l}0.910 \\
0.858\end{array}$} & \multirow{2}{*}{$\begin{array}{l}0.165 \\
0.107\end{array}$} & & & & & & & \\
\hline & & & PC1 & -0.057 & \multicolumn{2}{|c|}{-1.520} & -0.049 & \multicolumn{2}{|c|}{1.365} \\
\hline & \multirow{2}{*}{$\begin{array}{l}0.845 \\
0.755\end{array}$} & 0.479 & $\mathrm{PC} 2$ & -1.265 & \multicolumn{2}{|c|}{0.412} & 0.824 & \multicolumn{2}{|c|}{0.287} \\
\hline & & 0.573 & \multicolumn{7}{|c|}{ ANOVA } \\
\hline & 0.752 & 0.564 & & \multicolumn{2}{|c|}{ Cluster } & \multicolumn{2}{|c|}{ Error } & $\mathrm{F}$ & Sig. \\
\hline & $\begin{array}{r}0.086 \\
-0.524 \\
\end{array}$ & $\begin{array}{r}0.210 \\
-0.500 \\
\end{array}$ & & $\begin{array}{l}\text { Mean } \\
\text { Square }\end{array}$ & df & $\begin{array}{l}\text { Mean } \\
\text { Square }\end{array}$ & $\mathrm{df}$ & & \\
\hline SMEmk & 0.163 & 0.889 & PC1 & 6.202 & 3 & 0.179 & 19 & 34.72 & 0.00 \\
\hline SMEspro & $\begin{array}{l}0.157 \\
0259\end{array}$ & $\begin{array}{l}0.881 \\
0.841\end{array}$ & $\mathrm{PC} 2$ & 5.683 & 3 & 0.261 & 19 & 21.81 & 0.00 \\
\hline $\begin{array}{l}\mathrm{LP} \\
\text { GDP }\end{array}$ & $\begin{array}{l}0.259 \\
0.515\end{array}$ & $\begin{array}{l}0.841 \\
0.792\end{array}$ & & & & & & & \\
\hline SII & 0.621 & 0.752 & & & & & & & \\
\hline
\end{tabular}

The overall MSA (Measure of Sampling Adequacy) for the set of variables included in the analysis was 0.808 , which exceeds the minimum requirement of 0.50 for overall MSA. PCA requires the probability associated with Bartlett's Test of Sphericity to be less than the level of significance. The probability associated with the Bartlett test is $<0.001$ which satisfies this requirement. The Cronbach's Alpha for each component (0.797 and 0.948) is higher than the minimum acceptable level (0.60). To define the number of clusters in which the 23 countries will be classified, we used the hierarchical cluster analysis, Ward's method and Euclidean distance. Then, we used the k-means analysis to actually form the clusters. The results of the Snedecor's F-distribution (ANOVA) can be seen in Table 3. The formed clusters are statistically significant (significance level is smaller than 0.01). The analyzed $23 \mathrm{EU}$ Member States were enrolled in four clusters, as can be seen in Figure 4. Cluster 1 includes Baltic States and CEE states (Estonia, Latvia, Lithuania, Poland, Hungary, Romania and Slovakia). Cluster 2 named by us "southern cluster" includes Greece, Italy, Spain and Croatia. Cluster 3 named "continental cluster" groups Austria, Belgium, Germany, France, Ireland, Slovenia and Portugal. Cluster 4, the "northern cluster", includes Sweden, Denmark, Finland, Netherlands and United Kingdom.

Countries enrolled in the northern cluster can be characterized by a very high productive entrepreneurship. It can be noticed that these countries (except the United Kingdom) are distributed mainly in relation to the positive meaning of the variables that form the PC1. The Nordic EU countries recorded a high GEDI value from 0.5 to 0.63 . Sweden together with Denmark, having a GEDI of 0.63 points 
and are the EU leaders, ranked in the $2^{\text {nd }}$ and $3^{\text {rd }}$ places (after the USA) out of 118 countries. In the case of these countries, the level of opportunity-driven entrepreneurship is also high. The values of SII and NRI are higher than in other countries. Denmark, Finland and Sweden are "innovation leaders" in Europe. The position of the United Kingdom, in the $2^{\text {nd }}$ quadrant, is due to the lower value of the PC2 variables. In the case of the innovative SMEs as a percent of total SMEs (technological innovation), the United Kingdom represents only $21.26 \%$ in comparison with Sweden where this value is $47.38 \%$ [12]. In the countries mentioned above, the institutional environment is favorable to the development of efficient businesses. In the Ease of Doing Business Rank, these countries are ranked between 5-14 (except the Netherlands ranked $28^{\text {th }}$ out of 189 countries) and, at the same time, the Index of Economic Freedom, which has a positive impact on the quality of entrepreneurship, is also high.

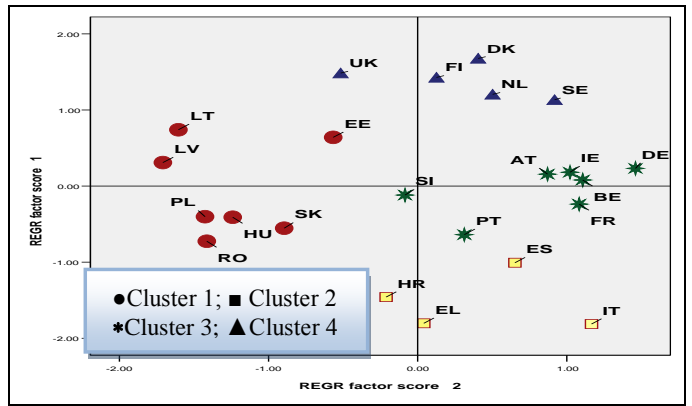

Source: Own calculations based on data [4], [12], [13], [21], [28], [29], [30], [32].

Figure 4

Clusters of entrepreneurial activity efficiency in EU obtained by PCA

Countries in the continental cluster can be characterized by a medium toward high productive entrepreneurship. Countries from this cluster, except Slovenia are on the right side of Figure 4, being characterized by a high value of the variables included in PC2. In these countries, the level of the innovative entrepreneurship is the highest, both technological innovations and non-technological innovations. After SII, 5 countries out of 7 included in the cluster are "innovation followers". Germany is an "innovation leader" and Portugal a "moderate innovator". Slovenia is placed in the third quadrant, but close to the origin because the level of innovative SMEs is low, almost $60 \%$ of the value calculated in the case of Germany. The ImprovementDriven Opportunity Entrepreneurial Activity indicator has high value not so far from the northern cluster average. This cluster was operating in 2011 at $84 \%$ from GEDI average of the northern cluster. Comparatively with the northern cluster, the institutional quality, technological readiness (measured by NRI) and competitiveness present a deficiency. In these respects, these countries are behind the northern cluster countries. 
Countries which belong to the Southern Cluster can be characterized by an entrepreneurial activity having low level venture output, with low impact on economic development, measured by GDP/capita. This group of countries is characterized by the lowest GEDI overall, having the lowest entrepreneurial aspirations sub-index. Within this cluster, the countries show heterogeneity. Croatia and Greece are situated very close to PC1 in a negative sense and tend to be closer to Cluster 1. This means that "necessity entrepreneurship" is more accentuated than in Italy and Spain. Italy's position in quadrant 4 and outside the "correlation circle" is due to the high value of GDP/capita, SMEs introducing marketing or organizational innovations as a percentage of SMEs and SII value, comparatively with the peer countries in the cluster. Moreover, it is differentiated with an early-stage of Entrepreneurial Activity. Based on SII, all peer countries are "Moderate innovators". According to GCI [29], Croatia is in transition from stage 2 (Efficiency-driven) to stage 3 (Innovation-driven) and the other peer countries are Innovation-driven economies.

Cluster 1, which consists of the Baltic States and CEE States, shows the highest level of necessity entrepreneurship. This cluster is very far from the PC2 (-1.26). Thus, some of the indicators such as labor productivity, economic development and innovativeness have the lowest values. A low level of economic performance can be observed. The GDP/capita average is only $23.8 \%$ of the GDP/capita realized by the countries from the northern cluster and the labor productivity is $62 \%$. Concerning innovation among peer countries, heterogeneity can be observed. Estonia has the highest level of innovativeness among peer countries, being "Innovation follower"; followed by "Moderate innovators" countries such as Hungary, Lithuania, Slovakia; and "Modest innovators" as Romania, having below $50 \%$ of the EU27 innovation performance. Estonia has the highest number of innovative SMEs and the impact on the economic development is also the highest among peer countries. The Baltic States are situated in the $2^{\text {nd }}$ quadrant because in these countries the necessity entrepreneurship is lower than in the CEE countries. Regarding competitiveness, based on GCI, 6 countries from this cluster are enrolled as economies in transition from stage 2 to stage 3 , and the $7^{\text {th }}$, Romania, is considered an efficiency-driven economy.

Making an analysis among clusters, it can be noticed that countries acknowledged as having productive entrepreneurship are all situated in the northern cluster and have the highest level of opportunity entrepreneurship. The Baltic and CEE countries have the highest level of necessity entrepreneurship among clusters, as can be seen in Figure 5. 


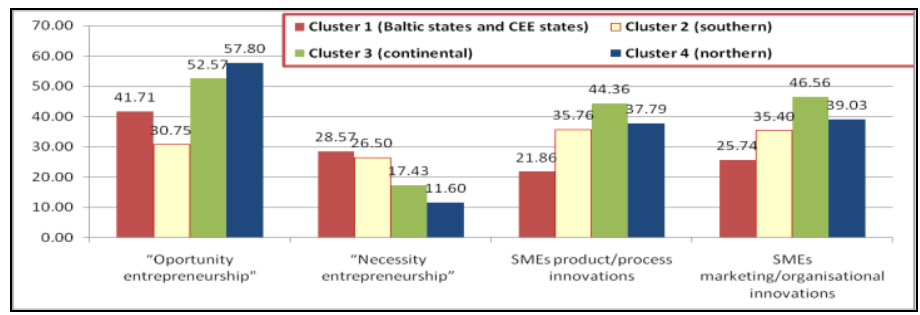

Source: Own calculations based on data provided by [12], [32]

Figure 5

Comparative analysis of entrepreneurial activity among clusters

Regarding hypothesis $\mathbf{H 5 a}$, the results indicate that entrepreneurship can have a positive impact on the national economy and in this respect we have to analyze the output not only at venture level. Sauka emphasized that the link between the degree of entrepreneurial activity and economic growth should not be limited to venturelevel performance but rather be measured by employment rate at national level. Different indicators are proposed to measure the entrepreneurship contribution at societal level, [22]. We used longitudinal data to analyze the evolution of selfemployment in EU28. The output at societal level measured by employment shows also high differences between transition and developed economies, but countries which belong to the $4^{\text {th }}$ cluster, as can be seen in Figure 6 , are not situated in the last places in this case. Self-employment does not have a significant impact on national and global markets, but its role in the national economy cannot be contested. In EU member states, a strong negative relationship was identified between selfemployment and the density of large enterprises $(\rho=-0.513, \mathrm{p}<0.01)$.

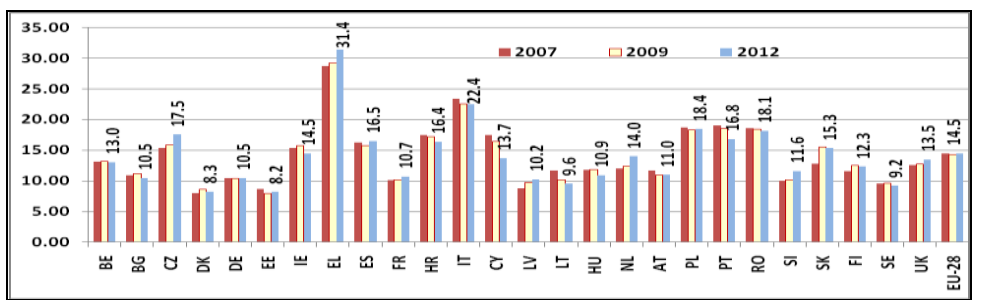

Source: Own calculations based on data provided by [13]

Figure 6

Self-employment in EU28 (2007-2012)

In transition economies, the entrepreneurial activity can be considered productive at the societal level, thus hypothesis $\boldsymbol{H} \boldsymbol{5} \boldsymbol{b}$ is confirmed. Moreover, transition economies continue to offer, at least on the same level self-employment, as can be observed in Figure 7. The obtained results sustain the affirmation that the main contribution of SMEs to economic development can be measured through employment generation and innovativeness, and the affirmation that the importance of entrepreneurship is reflected in total SME output at societal level [22]. 


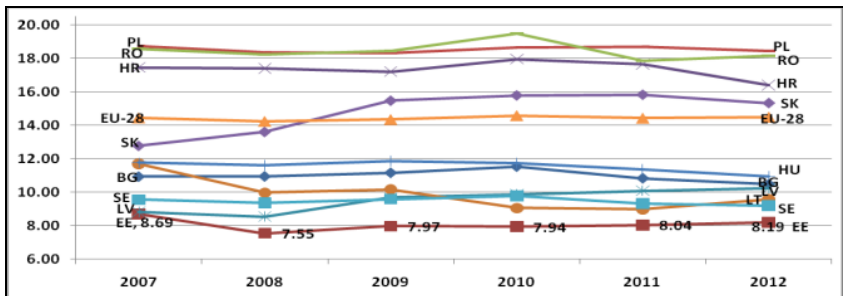

Source: Own calculations based on data provided by [13]

Figure 7

Self-employment rate in transition countries, Sweden (EU leader by GEDI) and EU28, 2007-2012

Furthermore, hypotheses $\mathbf{H 6 ,} \boldsymbol{H 7}$ and $\boldsymbol{H 8}$ will be tested regarding barriers to productive entrepreneurship, to formulate tasks to reduce the distance of the transition economies to the northern cluster. To become closer to the northern cluster which is characterized by very high productive entrepreneurship, improvements at both the individual and institutional levels must be made. Different conditions must be fulfilled by these countries to make their enrolment in the innovation-driven stage possible. It is well-known that productive entrepreneurship needs a favorable institutional environment but, on the other hand, productive entrepreneurship gives a venture-level performance, hence has a positive impact on economic development and permits its enrolment in a superior economic stage. To determine the barriers to productive entrepreneurship, we examine the constituent pillars of the indicators used in this study. The GEDI methodology focuses on quality, thus for our purpose, this is most important. Analyzing its pillars [4], all transition economies have a low value (on a scale 01), on the process innovation pillar (Table 4), suggesting the true value of hypothesis $H 6$.

Table 4

'Efficiency' of National System of Entrepreneurship and Pillars of GEDI

\begin{tabular}{|c|c|c|c|c|}
\hline & $\begin{array}{l}\text { 'Efficiency' } \\
\text { relative to the EU } \\
\text { leaders of } \mathrm{NSE}^{*}\end{array}$ & \multicolumn{3}{|c|}{ Worst Three GEDI Pillars } \\
\hline HU & $55.56 \%$ & Risk Capital & $\begin{array}{c}\text { Process } \\
\text { Innovation }\end{array}$ & $\begin{array}{l}\text { Opportunity } \\
\text { Perception }\end{array}$ \\
\hline PL & $58.73 \%$ & Opportunity Start-up & Risk Capital & Process Innovation \\
\hline SK & $57.14 \%$ & $\begin{array}{l}\text { Quality of Human } \\
\text { Resources }\end{array}$ & $\begin{array}{l}\text { Opportunity } \\
\text { Perception }\end{array}$ & Process Innovation \\
\hline BG & $49.21 \%$ & Risk Capital & $\begin{array}{c}\text { Process } \\
\text { Innovation }\end{array}$ & Technology Level \\
\hline HR & $53.97 \%$ & Process Innovation & Risk Capital & $\begin{array}{l}\text { Opportunity } \\
\text { Perception }\end{array}$ \\
\hline RO & $47.62 \%$ & Technology Level & Risk Capital & Process Innovation \\
\hline
\end{tabular}


The main cause for this extremely reduced level of the Process Innovation pillar is determined by the very low level of public-private investment in $R \& D$, as it can be noticed in Table 5 .

Table 5

Barriers to productive entrepreneurship

\begin{tabular}{|c|c|c|c|c|c|c|c|c|}
\hline & \multicolumn{2}{|c|}{$\begin{array}{c}\text { Public R\&D } \\
\text { expenditures as } \\
\% \text { of GDP }\end{array}$} & \multicolumn{2}{|c|}{$\begin{array}{c}\text { Business R\&D } \\
\text { expenditures as } \\
\% \text { of GDP }\end{array}$} & \multicolumn{2}{|c|}{$\begin{array}{l}\text { Ease of Doing } \\
\text { Business Rank }\end{array}$} & \multicolumn{2}{|c|}{$\begin{array}{l}\text { Index of } \\
\text { Economic } \\
\text { Freedom }\end{array}$} \\
\hline & 2007 & 2011 & 2007 & 2011 & $\begin{array}{c}2009 \text { Rank } \\
\text { (181 countries) }\end{array}$ & $\begin{array}{c}2013 \text { Rank } \\
\text { (189 countries) }\end{array}$ & 2007 & 2011 \\
\hline BG & 0.31 & 0.26 & 0.14 & 0.30 & 45 & 58 & 62.7 & 65 \\
\hline $\mathrm{HU}$ & 0.47 & 0.43 & 0.49 & 0.75 & 41 & 54 & 64.8 & 67.3 \\
\hline PL & 0.39 & 0.53 & 0.17 & 0.23 & 76 & 45 & 58.1 & 66 \\
\hline RO & 0.31 & 0.31 & 0.22 & 0.17 & 47 & 73 & 61.2 & 65.1 \\
\hline SK & 0.28 & 0.43 & 0.18 & 0.25 & 36 & 49 & 69.6 & 68.7 \\
\hline HR & 0.47 & 0.42 & 0.33 & 0.34 & 41 & 89 & 53.4 & 61.3 \\
\hline SE & 0.92 & 1.03 & 2.47 & 2.34 & 17 & 14 & 69.3 & 72.9 \\
\hline EU-27 & 0.66 & 0.75 & 1.18 & 1.27 & & & & \\
\hline
\end{tabular}

Source: Own construction based on data provided by [12], [21], [28]

Testing of hypothesis $\mathbf{H 6}$ indicates a strong relationship between SII and GDP/capita $(\rho=+0.925, \mathrm{p}<0.001)$; and a strong relationship between SII and GCI $(\rho=+0.897, p<0.001)$. Therefore, innovation can be considered a main driver of productive entrepreneurship. Figure 8 shows that the Baltic States and the CEE States have a very low level of SII compared to the northern cluster.

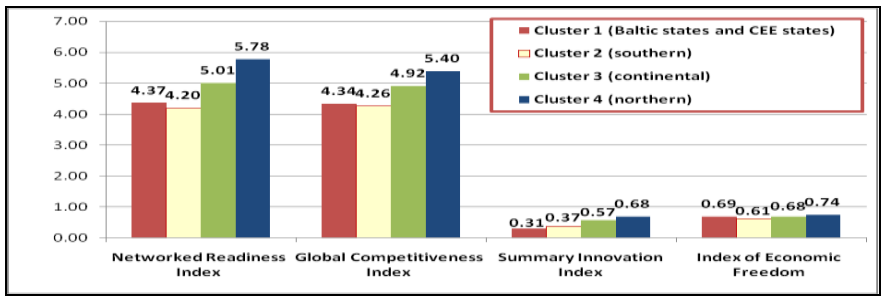

Source: Own calculations based on data provided by [12], [21], [29], [30]

Figure 8

Competitiveness, technological readiness, innovation and institutional environment among clusters

Testing of hypothesis $\boldsymbol{H} 7$ indicates a strong relationship between indicators having an important role in the quality of entrepreneurial activity, as can be seen in Table 6. The impact of the quality of institutions on productive entrepreneurship is also shown in Figure 8. We can observe that countries from the northern cluster have the highest value on the quality of institutions. 
Table 6

Institutional environment and productive entrepreneurship in EU countries ${ }^{*} \mathrm{p}<0.001$

\begin{tabular}{llcc}
\hline$\rho^{*}$ Pearson correlation coefficient & GEDI & GCI & NRI \\
\hline Ease of Doing Business rank & 0.717 & 0.742 & 0.836 \\
Index of Economic Freedom & 0.675 & 0.727 & 0.758 \\
\hline
\end{tabular}

Source: Own calculations based on data provided by [4], [21],[28], [29], [30]

Regarding hypothesis $\boldsymbol{H} \boldsymbol{8}$, we started our research looking for an answer to the following issue: Why is the intensity of the entrepreneurial activity not reflected in venture-level performance in the case of transition economies? We studied the relationship between the density of SME's and GDP/capita and the density of large enterprises and GDP/capita in the EU countries (Figure 9a and 9b). As for the relationship between the average density of SMEs and the level of development of the countries, data in Figure 9a show that no statistically significant relationship was identified between the two indicators, in 2011, at the level of the EU countries.

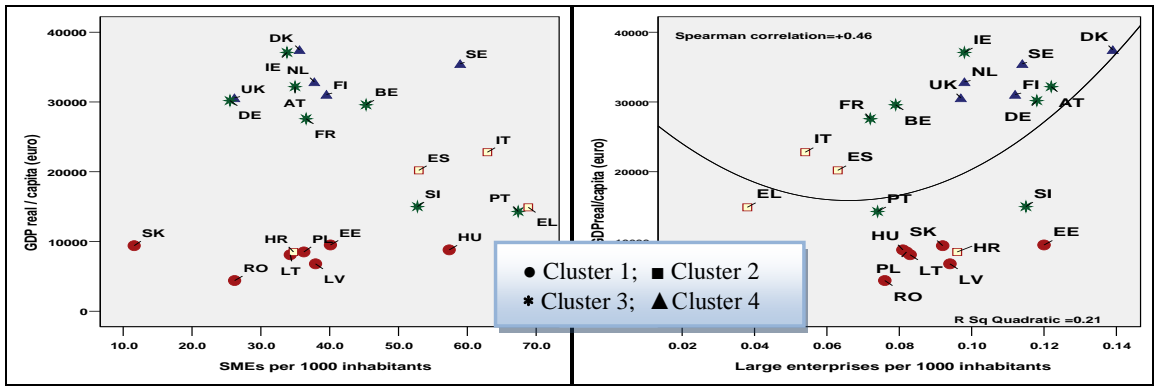

Source: Own calculation based on data provided by [13], [31]

Figure 9

(a) The density of SMEs and economic development, EU, 2011- statistically insignificant relationship

(b) Positive relationship between the density of large enterprises and economic development, EU, 2011

Therefore, the existing gaps on the level of economic development cannot be explained by disparities in the entrepreneurial activity, expressed by the density of SMEs. The study regarding the relationship between the density of large enterprises and GDP/capita (Figure 9b) shows that in countries with a low density of large enterprises, the GDP/capita is reduced as well (the case of transition economies). In developed economies, especially northern countries, the high density of the large companies is accompanied by a high level of GDP/capita. Labor productivity is higher in large companies than in SME's, because of the scale economies, the intensive use of capital, as well as a higher degree of technology compared to the existing one in SME's.

Figure 10 illustrates that in countries with a very low level of GDP/capita, the density of large enterprises is also reduced and longitudinal data show that this tendency is not increasing. Hence, hypothesis H8 is confirmed. 


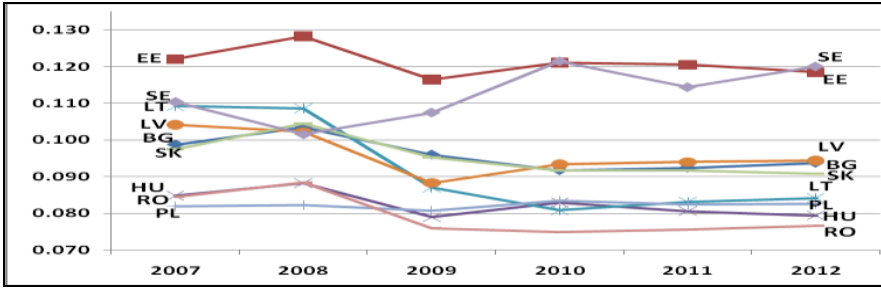

Source: Own calculation based on data provided by [13], [31]

Figure 10

Density of large enterprises (over 250 employees)

\section{Discussion and Conclusions}

The hypotheses in this study have been successfully supported by empirical data. Specifically, hypothesis H4 indicates that EU Member States should be enrolled in clusters because of the strong relationships between the variables which characterize the entrepreneurial activities performance. The EU member countries were grouped based on the efficiency of the entrepreneurial activity, our research being focused on productive entrepreneurship. The name of clusters was given by the countries geographical position within the cluster. We identified, for the analyzed, countries the main factors which have a significant impact on high output, starting with the differences between the clusters and then by exploring the frame of the cluster, countries with the greatest distance from the centre of the cluster.

Within the Northern Cluster, are the countries with the best performance in the $\mathrm{EU}$, leaders in the world, related to the considered indicators, they being ranked in the first places. These countries are the most innovative and competitive, with the highest density of large enterprises, high quality of institutions and a high number of innovative SME's. In this cluster, the United Kingdom is at the furthest distance from the centre. This can be explained by the low level of innovative SME's from the total SME's. In the United Kingdom, the necessity driven entrepreneurship is the highest compared to its peer countries and the entrepreneurial aspiration is not sufficiently developed. Longitudinal data show that self-employment is increasing. The density of SME's and large enterprises is the lowest in the cluster.

Regarding the Continental Cluster, the enrolled countries show lower level of productive entrepreneurship than those grouped in the northern cluster. The general characteristics of the cluster presented in Section 4, indicate the national priorities for these countries. In this cluster, we have to analyze separately the case of Slovenia (SI) and Portugal (PT) situated at the greatest distance from the centre 
of the cluster. In the case of SI, the worst position within the cluster can be explained by the lowest level of economic development, measured by GDP/capita, and by the quality of entrepreneurial activities, having a low GEDI value, the NRI and GCI have the lowest level in the cluster which points out that the technological environment, its use and competitiveness must be improved. The position of PT in the cluster reveals the need to improve the quality of entrepreneurship; the GEDI value has the lowest level in the cluster. PT has a better position because the share of innovative SME's is higher. The position of Ireland in the cluster, is central, but our results show some special characteristics such as the highest level of necessity entrepreneurship, the lowest density of SME,s and the highest density of large enterprises. Labor productivity has the highest position in the cluster which explains the fact that the GDP/capita is at the highest level in EU23 after Denmark.

Countries in the Southern Cluster manifest the highest dispersion in relation to the PC2 variables; this cluster is very far from PC1. Croatia (HR) belongs to this cluster, but it can be characterized by the highest level of necessity entrepreneurship and also improvement driven entrepreneurship related to its peer countries. However, the entrepreneurial activity has the lowest impact because of the lowest level of labor productivity. HR needs to improve the innovative performance having the lowest level of SII, the technological environment and its use. In the case of HR, GCI through its pillars needs to be analyzed to detect why it shows the lowest level. Italy (IT) has the lowest level of improvement entrepreneurship in the EU and the highest GEDI value compared to its peer countries which explains the highest level of economic output in the cluster. Greece (EL) presents the lowest GEDI value and has the highest level of self employment. The results show that IT and EL have the highest density of SMEs, but the percentage of innovative SMEs is the lowest in the cluster, having a lower impact on economic development.

Transition economies are situated in the $1^{\text {st }}$ cluster [9]. Concerning productive entrepreneurship, these countries lag behind other EU Member states. The Baltic States and CEE countries must be treated in a different way. The low level of output measured by GDP/capita and labor productivity is a common characteristic. In Baltic States, the improvement driven entrepreneurship is higher than in CEE countries. Based on our own calculations, Romania (RO) has the lowest level of necessity entrepreneurship. In this respect, it is situated close to the Baltic States. In Hungary (HU), the density of SMEs is very high and can be compared with the situation of Sweden, but unfortunately, the entrepreneurial activities are unproductive. Estonia (EE) followed by Latvia (LV) has the highest density of large enterprises, but the contribution of GDP/capita is at a very low level. The main problem, in transition economies, is innovativeness and the very low number of innovative SMEs. The quality of institutions is also lower in CEE countries than in Baltic States. 


\section{Recommendations}

The main purpose of this paper is to identify the transition economies barriers to productive entrepreneurship in the European context. Therefore, recommendations will be formulated relative to this aspect.

Transition economies must formulate policies which encourage and sustain the improvement of entrepreneurial activities efficiency to increase the venture level output. The obtained results demonstrate that, between the transition countries, there are differences which indicate that a different treatment is needed; the priorities are different in each and every country. The low level of the values on the Risk Capital pillar reflects that business financing and undercapitalization is a critical weakness of transition countries' start-ups and new ventures.

Croatia was enrolled in the continental cluster because the share of innovative SME's is higher than in the other transition economies, and labor productivity is the highest after Slovakia (SK). The quality of institutions has to be improved. Moreover, there is a need to improve the quality of entrepreneurial activities. The low value of NRI shows that the nation's degree of preparation to participate in and benefit from information and communication technology developments has to be increased.

Estonia, according to the analyzed indicators, is the leader of the transition economies. The country should increase the labor productivity through the improvement of the quality of entrepreneurial activities.

Latvia, having the lowest GEDI value between the Baltic States, needs to improve the quality of entrepreneurial activities. The innovative capacities have to be ameliorated. Labor productivity needs to be increased.

Lithuania needs to improve the entrepreneurial attitudes, the innovative capacities and the quality of institutions.

Hungary needs to improve the quality of entrepreneurial activities; 'the Efficiency' relative to the EU leaders of National System of Entrepreneurship (NSE) is $55.56 \%$. The worst GEDI pillars, which need improvement, are risk capital, process innovation and opportunity perceptions. The quality of institutions requires improvement. The number of innovative SME's needs to be increased, and policies that ameliorate innovative capacities are required.

Poland needs to improve the innovative performance. The quality of entrepreneurial activities has to be improved; 'the Efficiency' relative to the EU leaders of NSE is $58.73 \%$. The worst GEDI pillars are opportunity start-up, risk capital and process innovation. Poland requires policies to reduce the necessity driven entrepreneurship.

Romania needs to improve the entrepreneurial activities performance, 'the Efficiency' relative to the EU leaders of NSE is $47.62 \%$, the lowest percentage 
between transition economies. The GEDI value shows that entrepreneurial attitudes and abilities are not sufficiently developed; the actual level of quality is not able to produce high output. The GEDI value and its sub-indexes show that Romania has to increase the technology level, risk capital and process innovation. It needs to be analyzed why the improvement driven entrepreneurship produces the lowest level of GDP/capita between EU states. In this respect, a comparative analysis is required with Slovakia, Croatia, Estonia, since they have approximately the same density of SMEs but with significantly higher output than in the case of Romania. The density of large enterprises has to be increased and policies to develop the labor productivity are required. In Romania, the entrepreneurial activities are the most unproductive. The quality of the institutions and environment has to be assessed. Policies are needed to improve the quality of institutions. Romania has the lowest value of DB, EFI compared to its peer countries.

Slovakia needs to improve the quality of entrepreneurial activities; 'the Efficiency' relative to the EU leaders of NSE is $57.14 \%$. The worst GEDI pillars are quality of human resources, opportunity perception, and process innovation. The entrepreneurial activities are the most productive between transition economies. Thus, it can be considered the best practice example. The number of SMEs has to be extended.

Bulgaria was not enrolled in the cluster analysis because of the missing GEM data. Based on GEDI, 'the efficiency' relative to the EU leaders of NSE is $49.21 \%$. It has to improve risk capital, process innovation, and technology level. It also needs to improve the quality of institutions. Policies to improve the labor productivity are required, in this respect it is situated on the last place. Moreover, it needs to improve the innovative capacities.

Future research. The findings in this paper highlight the status of performance of transition economies' entrepreneurial activities, in the European context. The authors identified obstacles to productive entrepreneurship. The primary factors contributing to the movement between clusters should be examined. According to this study, EU Member States require special and different treatment. To formulate policies in concordance with priorities, the prioritization of the needs would be an interesting topic for future research.

\section{References}

[1] Aidis, R., Sauka, A.: Entrepreneurship in a Changing Environment. Analyzing the Impact of Transition Stages on SME Development. RENT (2005) Welter edition, online publication, www.ecsb.org

[2] Ács, Z. J., Szerb L.: The Global Entrepreneurship Index (GEINDEX), Foundations and Trends in Entrepreneurship (2009) Vol. 5, No. 5, pp. 341435

[3] Acs, Z. J., Szerb, L.: The Global Entrepreneurship and Development Index, Conference 2010 on "Opening Up Innovation: Strategy, Organization and 
Technology" at Imperial College London Business School, June 16-18

[4] Ács, Z. J., Szerb L., Autio, E.: Global Entrepreneurship and Development Index 2013, Edward Elgar Publishing Limited. London

[5] Baumol, W. J. Entrepreneurship: Productive, Unproductive, and Destructive Journal of Political Economy (1990) Vol. 98, No. 5, pp 893921

[6] Chilea D. L'espace fiscal Europeen, The Juridical Current, No. 4, 2009, pp. $38-50$

[7] Chris, D., Xiaofeng, H.: K-Means Clustering via Principal Component Analysis. $21^{\text {st }}$ International Conference on Machine Learning, pp. 1-9, Banff, Canada (2004) University of Texas Arlington

[8] Douhan, R., Henrekson, M.: Productive and Destructive Entrepreneurship in a Political Economy Framework. Stockholm, Sweden; Research Institute of Industrial Economics; IFN Working Paper (2008) No. 761

[9] EBRD Transition Report. Integration across borders, European Bank for Reconstruction and Development, 2012

[10] Estrin, S., Meyer, EK., Bytchkova, M.: Entrepreneurship in Transition Economies, Oxford Handbook of Entrepreneurship (2008) Oxford University Press

[11] Everit, B. S., Landau, S., Leese, M., Stahl, D. Cluster Analysis, $5^{\text {th }}$ ed. Willey, 2011

[12] EU. The Innovation Union Scorebord. Research and IUS EC, 2013, Jan. 9

[13] Eurostat database, 2013. Retrieved November 10, 2013. http://epp.eurostat.ec.europa.eu/portal/page/portal/statistics/search_database

[14] Fagerberg, J., Sapprasert, K.: National innovation systems: The emergence of a new approach. Science and Public Policy (2011) 38(9), Nov, pp 669-679

[15] Global Entrepreneurship Monitor (GEM) Reports; Retrieved Nov. 2, 2013, from http://www.gemconsortium.org/docs/cat/1/global-reports

[16] Gros, D., Steinherr, A.: Economic Transition in Central and Eastern Europe: Planting the Seeds. Cambridge: Cambridge University Press; 2004

[17] Harper, A. D.: Foundations of Entrepreneurship and Economic Development, New York: Routledge, 2003

[18] Jolliffe, I. Principal Component Analysis, $2^{\text {nd }}$ ed. New York: Springer; 2002

[19] Lumpkin, G., Dess, G. Clarifying The Entrepreneurial Orientation Construct and Linking It To Performance; Academy of Management Review (1996) pp. $135-172$

[20] Miller, D.: The Correlates of Entrepreneurship in Three Types of Firms. 
Management Science (1983) pp. 770-791

[21] Miller, T., Holmes, K. R., Feulner, E. J.: Index of Economic Freedom. Promoting Economic Opportunity and prosperity, The Heritage Foundation and Dow Jones \& Company, Inc; 2013

[22] Sauka, A.: Productive, Unproductive and Destructive Entrepreneurship: A Theoretical and Empirical Exploration. Michigan: The William Davidson Institute At The University Of Michigan, 2008

[23] Simonová, S.: Identification of Data Content Based on Measurement of Quality of Performance. E+M Ekonomie a Management (2012) pp. 128-137

[24] Smallbone, D., Welter, F.: Conceptualising Entrepreneurship in a Transition Context. International Journal of Entrepreneurship and Small Business, Vol. 3, Nr. 2, 2006, pp. 190-206

[25] Smith, I. L.: A tutorial on Principal Components Analysis, 2002, Febr 26

[26] Sobel, R. S: Testing Baumol: Institutional Quality and the Productivity of Entrepreneurship. Journal of Business Venturing, 2008, 23; pp. 641-655

[27] Szabo, K. Z., Soltes, M., Herman, E.: Innovative Capacity and Performance of Transition Economies: Comparative Study at the Level of Enterprises. E\&M Economics and Management (2013) pp. 52-67

[28] World Bank-WB. Doing Business: Smarter Regulations for SMEs, International Bank for Reconstruction and Development, 2013

[29] World Economic Forum; The Global Competitiveness Report 2013-2014

[30] WEF, The Global Information Technology Report, 2013

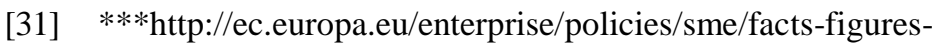
analysis/performance-review/index_en.htm *** GEM database http://www.gemconsortium.org/key-indicators

[33] ***http://ec.europa.eu/:http://ec.europa.eu/enterprise/policies/sme/promotin gentrepreneurship/index_en.htm 